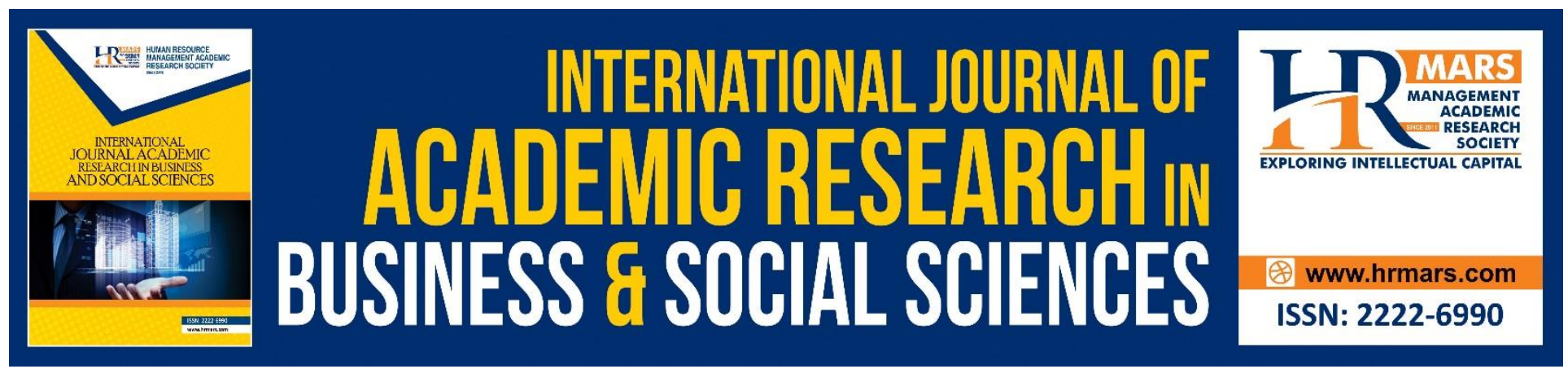

\title{
Financial Sector Policies and Economic Growth: Evidence From Insurance Sector in Nigeria
}

Lyndon M. Etale and Adesuwa R. Edoumiekumo

To Link this Article: http://dx.doi.org/10.6007/IJARBSS/v10-i9/7718

DOI:10.6007/IJARBSS/v10-i9/7718

Received: 04 June 2020, Revised: 05 July 2020, Accepted: 09 August 2020

Published Online: 16 September 2020

In-Text Citation: (Etale, and Edoumiekumo, 2020)

To Cite this Article: Etale, L. M., and Edoumiekumo, A. R. (2020). Financial Sector Policies and Economic Growth: Evidence From Insurance Sector in Nigeria. International Journal of Academic Research in Business and Social Sciences. 10(9), 155-169.

Copyright: (c) 2020 The Author(s)

Published by Human Resource Management Academic Research Society (www.hrmars.com)

This article is published under the Creative Commons Attribution (CC BY 4.0) license. Anyone may reproduce, distribute, translate and create derivative works of this article (for both commercial and non-commercial purposes), subject to full attribution to the original publication and authors. The full terms of this license may be seen at: http://creativecommons.org/licences/by/4.0/legalcode

Vol. 10, No. 9, 2020, Pg. 155 - 169

http://hrmars.com/index.php/pages/detail/IJARBSS

JOURNAL HOMEPAGE

Full Terms \& Conditions of access and use can be found at http://hrmars.com/index.php/pages/detail/publication-ethics 


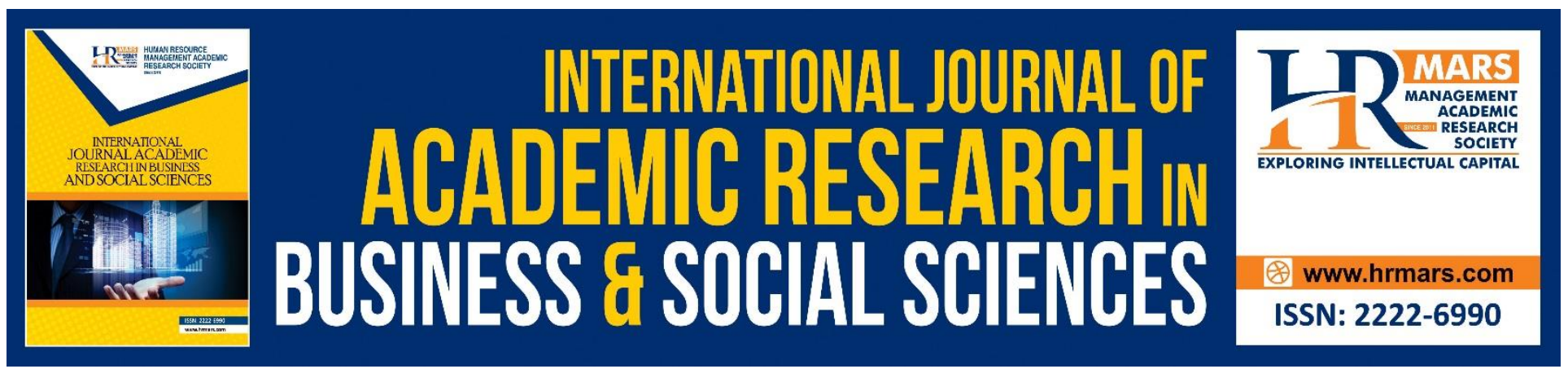

\title{
Financial Sector Policies and Economic Growth: Evidence From Insurance Sector in Nigeria
}

\author{
Lyndon M. Etale (PhD) and Adesuwa R. Edoumiekumo (Mrs) \\ Department of Accounting, Faculty of Management Sciences, Niger Delta University, Wilberforce \\ Island, Bayelsa State, Nigeria
}

\begin{abstract}
This study investigated the financial sector policies and economic growth link in Nigeria with a focus more on the insurance sub-sector. The study adopted the time series research design, where data for evaluation covering the period 2010 to 2018 were obtained from several editions of the Central Bank of Nigeria (CBN) Statistical Bulletin. Gross capital formation, total insurance premium and total insurance investment were used to represent financial sector policies, while gross domestic product was used as proxy for economic growth. Data were analyzed using descriptive statistics and multiple regression technique assisted by E-views 10 software. The study found that gross capital formation and total insurance investment were significantly related to gross domestic product, while total insurance premium had insignificant effect on GDP. Also, gross capital formation and total insurance premium had negative effect on GDP, but total insurance investment was positively related to GDP. The study concluded that financial sector policies made statistically substantial contribution to the growth of the Nigerian economy with a coefficient of determination and probability of F-statistics values of 0.99246 and 0.00001 (less than 0.05 level of significance) respectively. It is therefore recommended that the regulatory authorities should put in place policies to make it attractive for Nigerians to patronize insurance business as this would translate to increased insurance investment and further result to growth of the Nigerian economy since insurance investment was found to have positive link with gross domestic product.
\end{abstract}

Keywords: Capital formation, Economic growth, Financial Sector policies, Investment, Insurance, Premium.

\section{Introduction}

Every business needs two types of capital which are fixed capital and working capital; fixed capital is raised from the capital market, while working capital is obtained from the money market (Babu, 2018). When a sufficient fixed and working capital is available, it helps the business to be able to settle its activities in operation by financing them. The financial system (comprising the capital and money markets) of any country plays a very vital role in the development or growth of its economy. It is a pivotal wheel that encourages the investment culture and savings behaviour which in turns create a bridge between investment and savings. This bridge facilitates the increase in markets and 
INTERNATIONAL JOURNAL OF ACADEMIC RESEARCH IN BUSINESS AND SOCIAL SCIENCES Vol. 10, No. 9, 2020, E-ISSN: 2222-6990 @ 2020 HRMARS

helps the financial expansion. It increases the quantum of savings volume through efficient mobilization and various financial measures provided. The measures that are provided helps in boosting the output of an economy by providing financial assistance to the corporate world to create room for expansion not increasing their standard of living.

Financial institutions also help investors with the right decision to invest and thereby increasing in financial asset as the GDP percentage by increasing customers in the financial system. Arestis and Demetriades (1997) posit that the connection between financial development and economics growth had received consumable attention; a development which has the potential of bringing about economic growth. It should be noted that a discussion on financial institutions covers banking, insurance and pension fund managers; but the primary focus of this study is on the insurance subsector of the financial system.

Financial institutions act as financial intermediaries connecting the savings sector to the investment sector; and their existence permits the economy to undertake projects that have high expected returns but are risky, lumpy and illiquid (Montiel, 1995). Insurance companies therefore play an important role by providing cover for high risk businesses. Insurance companies are among the non bank financial institutions which plays an important role in the financing link within the financial system in an economy. The primary aim of Insurance is to provide decrease in risk faced by firms and businesses. Insurance companies plays dual role on the field of the economy: one as a risk bearer and manager and secondly as a base for capital formation.

In Nigeria, insurance company symbolizes the backbone of risk management in Nigeria. Insurance company plays a vital role in the sense that they constitute the biggest institutional investors in pension and mutual funds stocks and bonds. The impact on the growth of any economy relatively increases rather than declining due to the issues of boosting income difference and globalization. Insurance cover which is risk management cannot be separated from human activities because these activities cannot discount itself with risk. The insurance activities cannot disconnect itself with risk. The insurance companies help individual to come back to the position he was before the occurrence of the risk. The role played by insurance companies in the development of both developed and developing countries cannot be overemphasized because it has contributed positively to the growth of any economy. Economic activities are increasing over the years as the categories of risk are increasing also. The role which the insurance company has come to play is to prevent sudden and devastating risks which are undergone by individual, companies etc. When an economy is healthy and happy without environmental change it is said that development is viable.

\section{The Problem Statement}

The insurance sub sector as part of the financial system has contributed immensely to the growth of any economy. However, some researchers have argued that there is no relationship between financial system development and economic growth. Previous researches have shown how the insurance sector development relating to the growth of the Nigerian economy is limited due to the neglect of insurance patronage in Nigeria. The risk of operating a business in Nigeria now is very high due to the state of insecurity in Nigeria; and not just Nigeria but globally. The existence of insurance companies is to provide cover for increasing risk of doing business in the world.

Haiss and Sumegi (2008) found out from their study that there was a weak evidence for the growth supporting role of life assurance and explained their discovery with similarities to current findings in banking and stock market sector; that insurance companies, although growing in importance in 
financial intermediation, has received less attention than banks and stock markets. Previous studies have centered their research on the relationship between the financial development Sector - banks and stock markets, while insurance have been overlooked in time past (Boon, 2005; Outreville, 2013; Horng, Chang \& Wu, 2012; Yinusa \& Akinlo, 2013; and Hou \& Cheng, 2017). The neglect of the insurance sub-sector accounts for the lack of literature on this topic as according to UI Din, Regupathi and Abu-Bakar (2017), researchers have in recent times put attention on insurance sector development and economic growth nexus because of lack of sufficient literature and existing knowledge gap on the subject.

\section{Objectives of the Study}

The broad objective of this study was to examine the relationship between financial sector policies and the growth of Nigeria's economy with a special focus on the insurance sub-sector and by so doing contribute to the existing knowledge gap. The specific objectives of the study were as follows:

- To determine the effect of gross capital formation on gross domestic product in Nigeria;

- To ascertain the impact of total insurance investment on gross domestic product in Nigeria; and

- To examine the effect of total insurance premium on gross domestic product in Nigeria.

\section{Research Questions}

This study was guided by the following specific research questions:

- To what extent has gross capital formation impacted on gross domestic product?

- To what extent has total insurance investment contributed to gross domestic product?

- What role has total insurance premium played on gross domestic product?

\section{Hypotheses Formulated}

The following hypotheses were formulated in the null form and tested in this study:

* Gross capital formation has no significant impact on GDP;

* Total insurance premium does not have significant effect on GDP; and

* Total insurance investment has not contributed significantly to GDP.

\section{Significance of the Study}

This study provided significant contribution to assist the regulatory authorities to formulate good policies that would be beneficial to the insurance industry and the Nigerian economy at large, by means of increasing insurance investments. The study has also made immense contribution to existing literature on the subject and would provide useful source of reference for future research. The rest of this paper is divided into four parts. Following the general introduction above in part two is the review of related literature, while part three covered the study methodology. Part four was devoted to the results of analysis and discussions, and finally, part five provided the summary, conclusion and recommendations.

\section{Review of Related Literature Conceptual Clarifications}

Insurance

Insurance is the business of providing risk against uncertainties and managing such risk for the insured and third parties. It is a means of indemnity against a future occurrence of an uncertain event. 
INTERNATIONAL JOURNAL OF ACADEMIC RESEARCH IN BUSINESS AND SOCIAL SCIENCES Vol. 10, No. 9, 2020, E-ISSN: 2222-6990 @ 2020 HRMARS

The process of providing cover for the occurrence of unforeseen events may bring about claims, and as result the insurer collects premium from the insured.

Insurance company

Insurance companies are non-bank financial institutions backed up by law to underwrite insurance otherwise known as the insurer. They collects premium from the insured and this is a veritable source of gross capital formation.

Economic Growth

Usually represented by gross domestic product or gross national output is the total monetary value all the goods and services produced within the territory of a nation. It is viewed as a sustained increase in net national output over a long period of time. It is considered as growth if the rate of increase in total output (goods and services) is greater than the rate of growth in the population of the country in question.

Relationship between insurance sector business and economic growth

Economic growth is a process where the drivers of an economy increase over time that leads to rise in the levels of national income. Skipper (1997) posits that the contribution of insurance markets activities which ranges from risk transfers, establishing investors and reimbursement agent can enhance economic growth through mobilization of domestic savings, allowing efficient management of different risk thereby boosting the accumulation of new capital, financial stability, aiding trade, supporting to mitigate losses and promoting a more efficient and fair sharing of domestic wealth. The growth in the life insurance market signifies considerable efforts put within the insurance industry. So many questions have been put across to how the life insurance package affect or impacts positively on the growth of an economy (Billah, 2013).

These funds will therefore boost economic activities which in turns improve financial and social stability, and thereby promote entrepreneurial activities. This explains the relationship between insurance and economic growth. Risk taking culture of insurance which indemnifies insurers by way of premium taking, helps insurance companies to gather this funds (premium) and plough it back to the economy by way of investing it in the capital markets, this premium will now be available to be used to provide loans to the public, private or government to finance their projects which will have a multiplier effect on the economy through increased consumption, employment, high trading, improved GDP and decrease in inflation. This will automatically influence the growth of the economy positively. The functions of insurance companies are similar to that of banking institutions so they should be seen to support and complement the banking industries.

The sharing of risk through insurance gives investors the confidence and it helps investors to venture into high risk business which brings economic growth. There is no need emphasizing the fact that without insurance cover firms that undergoes any loss will pay directly from their working capital budget which might affect its operation due to the magnitude of loss that the company may undergo. The link between insurance and economic growth is significant. Nigeria is a developing country and so many persons are yet to be informed concerning insurance companies activities. Every citizen should be sensitized about the products of the insurance sub sector of the financial system. Awareness will bring about investors in insurance company and this will boost the insurance activities; but premiums taken should be moderate to enable small entrepreneurs to take insurance cover which will in turn boost economic growth. This information flow concerning insurance cover should be made clear to the public so as not to discourage investors that would want to invest in form of taking an insurance cover. Before now so many persons have been discourage due to the fact 
INTERNATIONAL JOURNAL OF ACADEMIC RESEARCH IN BUSINESS AND SOCIAL SCIENCES Vol. 10, No. 9, 2020, E-ISSN: 2222-6990 @ 2020 HRMARS

that when it is time for an insured is to be indemnify a lot of questioning comes up which are frustrating and it makes the insured go through a lot of stress. This had made so many persons shy away or runaway from taking any insurance cover. For these group of people to be insured, there are some simple measures that can be suggested to customers that would lead to growth in their finance base (premium that will be collected), that is, rate of investment will be very high and will impact positively on the growth of the economy. Customers' needs suitable financial protection through the insurance cover they have undertaken.

\section{Empirical Review}

Studies Conducted in Other Countries

Peleckiene, Peleckis, Dudzeviciute and Peleckis (2019) examined the link between insurance and economic growth in $27 \mathrm{EU}$ countries using secondary data for the period 2004 to 2015. They employed descriptive statistics, correlation analysis and Granger causality test for data evaluation. Based on their findings, the study concluded that insurance sector development made higher contribution to economic growth in wealthy nations like Denmark, Finland, France, Ireland, The Netherlands and UK; insurance practices had significant positive effect on economic growth in Denmark, Finland, Luxembourg, and The Netherlands; insurance sector activities had significant negative effect on economic growth in Austria, Belgium, Estonia and Malta; and insurance practices had no impact on economic growth in Slovakia. Ouedraogo, Guerineau and Sawadogo (2018) examined the link between the development of the life insurance sector and economic growth in 86 developing countries using data covering the period 1996 to 2011. Time series secondary data for the study were obtained from the World Bank development indicators. The variables used for the study include total life insurance premium (independent variable) and GDP representing economic growth (dependent variable). Descriptive statistics and generalized moments method (GMM) were the tools employed for data analysis. The findings showed that insurance sector development had positive effect on economic growth, but the effect varied from country to country due to the different economic characteristics of the countries.

Lee, Yong and Lim (2018) investigated the relationship between insurance activities and economic growth, using data obtained from World Bank development indicators for 123 countries spanning 1967 to 2014. The variables used include GDP (dependent variable), life insurance premium and nonlife insurance premium (independent variables). The results based on static and dynamic panel data models showed significant causality link between insurance development and economic growth; but the relationship is varied from country to country according to income levels and location, leaving each country to independently formulate policies that may work in each environment. In a similar study, UI Din, Abu-Bakar and Regupathi (2017) investigated the relationship between insurance business and economic growth using data relating to 20 countries covering the period 2006 to 2015. The variables they used include GDP representing economic growth, net insurance written premium, insurance penetration and insurance density representing insurance sector activities. They employed Hausman test statistics for data analysis and the results confirmed that insurance activities had significant positive effect on economic growth; but non-life insurance business had a stronger impact on economic growth than life insurance practice.

Hou and Cheng (2017) examined the effect of life insurance, banking and stock markets on economic growth in 31 countries using secondary data for the period 1981 to 2008. The study adopted economic growth as the dependent variable, while bank credits to private sector, life insurance and 
INTERNATIONAL JOURNAL OF ACADEMIC RESEARCH IN BUSINESS AND SOCIAL SCIENCES Vol. 10, No. 9, 2020, E-ISSN: 2222-6990 @ 2020 HRMARS

stock market capitalization were used as the independent variables. They employed pooled mean group technique and generalized method of moment estimator for the analysis of data; and found that bank credits to the private sector had negative effect on economic growth, while life insurance and stock markets had no impact on economic growth. UI Din, Regupathi and Abu-Bakar (2017) also investigated the link between insurance and economic growth of 6 developed and developing countries for the period 1980 to 2015. The variables used include GDP representing economic growth (dependent variable), life insurance, non-life insurance, trade openness, stock market development, employment rate, foreign direct investment and banking development (independent variables). They employed panel auto-regressive distributed lagged (PMG/ARDL) method for data analysis. The results indicated as follows: employment rate and banking development had significant negative link with economic growth in the long run; FDI had significant relationship with economic growth in the long run; non-life insurance had short run significant positive link with economic growth for China, India, Malaysia, Pakistan, UK and USA; life insurance had significant positive association with economic growth for India, Pakistan and UK; and life insurance had significant negative link with economic growth for China, Malaysia and USA.

Outreville (2013) conducted a literature search involving 85 empirical studies on the relationship between insurance and economic growth. Their review provided sufficient evidence to enable them conclude that insurance development is a significant determinant of economic growth. Gollier (2003) study used a dynamic model of insurance demand to proffer reasons why businesses or individuals buy insurance policy or not to buy. The study showed that only liquidity trapped individuals generally buy insurance cover, whereas wealthy individuals purchase insurance only to cover catastrophic risks (whose loss potential exceed a large proportion of their yearly income. The liquidity constraint insurance regime explains the low contribution of the insurance sector to economic growth; it is not surprising therefore that in some developing economies such as Nigeria certain types of insurance products are made mandatory as a deliberate policy by government to support that sector.

Studies Conducted in Nigeria

Etale (2019) examined the association between insurance sector performance and economic growth in Nigeria using time series data obtained from the CBN for the period 2001 to 2017. The study adopted GDP as proxy for economic growth, while insurance investment, insurance premium and insurance claims were used as insurance sector activity components. He employed descriptive statistics and multiple regression analysis for data estimation. The study found that insurance premium and insurance investment had significant effect on GDP; concluding that the insurance subsector contributed substantially to economic growth in Nigeria. Similarly, Adebisi, Umukoro and Ohiani (2019) evaluated the contribution of local content policy to insurance premium income generation in Nigeria using secondary data from sampled 3 insurance firms for the period 2008 to 2016. Variables of the study include insurance premium income (dependent variable), local content policy, resource capacity and competitiveness (independent variables). The study employed Cronbach Alpha and correlation techniques for data analysis. The results showed that local content policy of insurance business in oil and gas contributed significantly to improve oil and gas insurance premium income in Nigeria.

Fashagba (2018) investigated the causality link between insurance sector performance and economic growth in Nigeria spanning the period 2007 to 2016 . Secondary data for the study was collected from the CBN. The study used OLS multiple regression analysis for data estimation. The results provided evidence that non-life insurance premium and total insurance premium had positive link with 
INTERNATIONAL JOURNAL OF ACADEMIC RESEARCH IN BUSINESS AND SOCIAL SCIENCES Vol. 10, No. 9, 2020, E-ISSN: 2222-6990 @ 2020 HRMARS

economic growth, whereas life insurance premium had negative association with economic growth. However, the relationship between economic growth and insurance sector activity components were not statistically significant. Similarly, Nwosa and Mustapha (2018) examined the impact of insurance development on economic growth for the period 1996 to 2014. Time series secondary data for the study was collected from the CBN, while OLS and Granger causality test were used for the analysis of data. The results indicated that insurance sector performance had insignificant impact on economic growth. It was recommended that government should put in place sound regulatory policies to sustain insurance sector development.

lyodo, Samuel and Inyada (2018) examined the effect of insurance sector development on economic growth in Nigeria using time series data obtained from CBN for the period 1988 to 2014. The variables used include non-life insurance penetration, insurance savings, insurance investment (independent variables); and gross domestic product growth rate (dependent variable). They employed unit root test, ARDL bound test and OLS regression techniques for the analysis of data. The results showed that non-life insurance performance had substantial positive contribution to economic growth. Fadun and Shoyemi (2018) also, investigated the influence of insurance investment funds to the growth of the Nigerian economy using secondary data collected from the CBN for the period 2000 to 2015. The study variables include gross domestic product representing economic growth (dependent variable) and total insurance investment (independent variable). The study employed Pearson's correlation coefficient and OLS technique as the tools for data analysis. They found a strong positive connection between insurance investment and gross domestic product.

Olushola and Uzoma (2018) examined the nexus between financial sector development and economic growth in Nigeria for the period 1981 to 2017 using secondary data collected from the CBN and Federal Bureau of Statistics. They used gross domestic product proxy for economic growth as the dependent variable, while the independent variables include total insurance income, total bank deposit assets, total stock market capitalization and broad money supply. Their analysis was based on Johansen co-integration test, Augmented Dickey Fuller and Philip-Peron unit root test, and error correction model. Their findings among others showed that total insurance income had significant positive association with economic growth.

Eze and Okoye (2013) examined the impact of insurance practice on economic growth in Nigeria using secondary data from 1980 to 2011. The study adopted GDP representing economic growth as the dependent variable, while the independent variables used to proxy insurance practice include insurance premium income and insurance investment income. The study employed unit root test, Johansen co-integration test and error correction model for the analysis of data. They found significant positive association between insurance practices and economic growth. Similarly, Yinusa and Akinlo (2013) investigated the relationship between insurance development and economic growth in Nigeria spanning a period of 25 years from 1986 to 2010. Among other independent variables, the study used gross capital formation and gross premium income to represent insurance development, whereas economic growth (the dependent variable) was measured by gross domestic product. Secondary data for the study were obtained from Central Bank of Nigeria and National Bureau of Statistics. They employed Augmented Dickey Fuller (ADF) unit root test and error correction model for data analysis. The results indicated that physical capital had positive effect on RGDP, and they concluded that insurance sector development made significant contribution to economic growth. 
INTERNATIONAL JOURNAL OF ACADEMIC RESEARCH IN BUSINESS AND SOCIAL SCIENCES

Vol. 10, No. 9, 2020, E-ISSN: 2222-6990 @ 2020 HRMARS

\section{Methodology}

\section{Research Design}

This study adopted time series ex post facto research design. This design is most suited for this study as it utilized already existing time series secondary data for its analysis.

\section{Variables of the Study}

The paper employed various statistical and econometrics tools to examine the relationship between financial sector policies with a focus on the insurance industry and the growth of the Nigerian economy. The study used gross capital formation (GCF), total insurance Premium (INP) and total insurance investments (INV) as independent variables, while gross domestic product (GDP) - a measure of economic growth was used as the dependent variable.

\section{Source of Data}

Secondary data for the study covering the period 2010-2018, were collected from various editions of the Central Bank of Nigeria (CBN) Statistical Bulletin. For this type of study this source is adjudged to be the most reliable source of data.

\section{Model Specification}

The model of the study which expressed gross domestic product as a function of insurance sub-sector components captured the relationship between the selected insurance sub-sector variables and the growth of the Nigerian economy. The model which has been used by previous researchers such as Etale and Uzakah (2020), Nwoye, Obiorah and Ekesiobi (2015), and Eze and Okoye (2013) to mention a few, is presented below:

$G D P=f(G C F, I N P, I N V)$

The above model was expressed as a linear equation as follows:

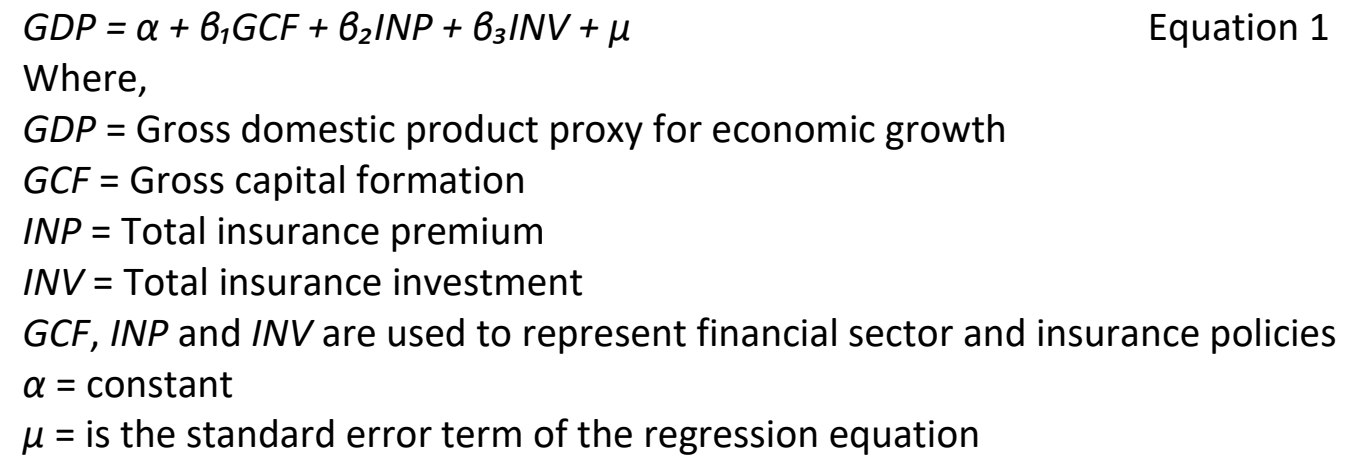

\section{Method of Data Analysis}

The study adopted descriptive statistics and multiple regression analysis as the statistical tools for data analysis with the aid of the E-views version 10, software. The statistical values of interest are the coefficients of the independent variables and their corresponding probability values; the coefficient of determination of the model, the probability of the F-statistics, the constant term and the standard error of the equation. The Durban Watson statistics was used to determine the absence of serial auto correlation among the variables. 
INTERNATIONAL JOURNAL OF ACADEMIC RESEARCH IN BUSINESS AND SOCIAL SCIENCES Vol. 10, No. 9, 2020, E-ISSN: 2222-6990 @ 2020 HRMARS

\section{Data Presentation, Results and Discussion \\ Data Presentation}

Table 1: Annual data on the study variables (GDP, GCF, INP and INV)

\begin{tabular}{ccccc}
\hline YEAR & GDP & GCF & INP & INV \\
\hline 2010 & 54.61 & 91.83 & 200.38 & 351.46 \\
2011 & 62.98 & 84.26 & 233.75 & 359.19 \\
2012 & 71.71 & 86.41 & 135.77 & 388.61 \\
2013 & 80.09 & 93.20 & 141.58 & 417.08 \\
2014 & 89.04 & 105.72 & 147.39 & 445.56 \\
2015 & 94.14 & 104.32 & 153.20 & 474.03 \\
2016 & 101.49 & 99.27 & 159.02 & 502.51 \\
2017 & 133.71 & 96.32 & 164.83 & 530.98 \\
2018 & 130.89 & 60.83 & 170.64 & 559.46 \\
\hline
\end{tabular}

Source: CBN Statistical Bulletin (various issues)

The data used for this study is presented in Table 1. GDP and GCF are stated in Trillions of the Nigerian Naira currency, while INP and INV are in Billions of Naira.

\section{Results and Discussion}

Descriptive Statistics

Table 2: Descriptive Statistics

\begin{tabular}{lcccc}
\hline & GDP & GCF & INP & INV \\
\hline Mean & 88.7400 & 91.3511 & 167.396 & 447.653 \\
Maximum & 130.890 & 105.720 & 233.750 & 559.460 \\
Minimum & 54.6100 & 60.8300 & 135.770 & 351.460 \\
Std. Dev. & 24.4571 & 13.5644 & 31.3179 & 74.7104 \\
Probability & 0.82433 & 0.27378 & 0.36300 & 0.71763 \\
Observations & 9 & 9 & 9 & 9 \\
\hline
\end{tabular}

Source: E-views 10 output

The descriptive statistics in Table 2 shows that the study variables; GDP, GCF, INP and INV have mean values of $88.74,91.35,167.39$ and 447.65 respectively. Their corresponding maximum and minimum values $130.89,105.72,233.75,559.46,54.61,60.83,135.77$ and 351.46 respectively. The standard deviation of the study variables are, $24.46,13.56,31.32$ and 74.71 respectively; indicating that INV is the most dispersed variable, while GCF is the least dispersed among the variables. The probability values of the study variables indicates that all the variables are normally distributed as each one of them is greater than 0.05 (that is, $0.82,0.27,0.36$ and 0.72 for GDP, GCF, INP and INV respectively). Regression Results

From the regression results in Table 3, the linear Equation 1 can be represented as stated below: $G D P=-25.79-0.23 G C F-0.031 N P+0.31 I N V+2.69$ Equation 2

Equation 2 above shows that the intercept or constant term is negatively signed, while the error term of the equation is positively signed. This implies that if all the independent variables were held constant, GDP growth would have been minus 23.10 units. It can be highlighted from Equation 2 too that the coefficients of gross capital formation (GCF) and total insurance premium (INP) are negatively signed; meaning that GCF and INP have negative effect on gross domestic product (GDP). 
INTERNATIONAL JOURNAL OF ACADEMIC RESEARCH IN BUSINESS AND SOCIAL SCIENCES Vol. 10, No. 9, 2020, E-ISSN: 2222-6990 @ 2020 HRMARS

On the other hand, total insurance investment (INV) with a positive arithmetic signed coefficient has positive effect on GDP. From the calculated probability values in Table 3, GCF and INV are significantly related to GDP, while INP has no significant effect on GDP as indicated by their respective P-values ( 0.03 and 0.00 for GCF and INV are less than 0.05 ; but 0.47 for INP is greater than the 0.05 level of significance).

Table 3: Multiple Regression Results

Dependent Variable: GDP

Method: Least Squares

Date: 08/09/2020 Time: 22:29

Sample: 20102018

Included observations: 9

\begin{tabular}{crrrr}
\hline \hline \multicolumn{1}{c}{ Variable } & Coefficient & Std. Error & t-Statistic & Prob. \\
\hline C & -25.7888 & 15.0500 & -1.71354 & 0.1473 \\
GCF & -0.22559 & 0.07740 & -2.91463 & 0.0332 \\
INP & -0.02793 & 0.03559 & -0.78458 & 0.4682 \\
INV & 0.31232 & 0.01449 & 21.5441 & 0.0000 \\
\hline \hline R-squared & 0.99246 & Durbin-Watson stat & 2.07709 \\
Adjusted R-squared & 0.98794 & & & \\
S.E. of regression & 2.68601 & & & \\
Prob.(F-statistic) & 0.00001 & & & \\
\hline \hline
\end{tabular}

Source: E-views 10 Output

Furthermore, the results in Table 3 indicates that the coefficient of determination of the overall study model (R-squared) of 0.99 shows that $99 \%$ of changes in GDP are explained by the combined effect of the variations in GCF, INP and INV. In addition, the adjusted R-squared value of approximately 0.99 indicates at $99 \%$ confidence level that the model used in evaluating the association between GDP and the independent variables was a proper and good fit; meaning the regression model which expressed GDP as a function of GCF, INP and INV was appropriate. Also, the Durban Watson statistics value of 2.07 which is approximately equal to the 2.0 benchmark indicates that there was no auto serial correlation among the independent variables (GCF, INP and INV). In the overall analysis, the coefficient of determination and the probability of F-statistic values of 0.99246 and 0.00001 respectively indicated that financial sector policies represented by gross capital formation (GCF), total insurance premium (INP) and total insurance investment (INV) made statistically substantial contribution to economic growth in Nigeria proxy by gross domestic product (GDP).

\section{Hypotheses Testing}

The decision rule for testing the hypotheses is that: if the calculated P-value is greater than 0.05 level of significance the null hypothesis would be accepted; otherwise if the calculated P-value is less than 0.05 then the null hypothesis is rejected.

1. Null Hypothesis One: There is no significant relationship between gross capital formation (GCF) and gross domestic product (GDP). 
INTERNATIONAL JOURNAL OF ACADEMIC RESEARCH IN BUSINESS AND SOCIAL SCIENCES Vol. 10, No. 9, 2020, E-ISSN: 2222-6990 @ 2020 HRMARS

The coefficient and P-value of GCF in Table 3 are -0.2356 and 0.0332 respectively. Since $0.03<0.05$, null hypothesis one is rejected. However, the coefficient of GCF has a negative sign. This means that GCF has a significant negative association with GDP. The implication being that a unit increase in GCF will bring about 0.2356 units decrease in GDP.

2. Null Hypothesis Two: There is no significant relationship between total insurance premium (INP) and gross domestic product (GDP).

The coefficient and P-value of INP in Table 3 are -0.0279 and 0.4682 respectively. Since $0.47>0.05$, 3. Null hypothesis two is accepted; and since the coefficient of INP is negatively signed it means that INP has a negative but insignificant link with GDP. By implication this means again that a unit increase in INP will lead to 0.0279 units decrease in GDP.

4. Null Hypothesis Three: There is no significant relationship between total insurance investment (INV) and gross domestic product (GDP).

5. Again from Table 3, the coefficient and P-value of INV are 0.3123 and 0.0000 respectively; and since $0.00<0.05$, null hypothesis three is rejected. The coefficient of INV has a positive sign. This means that GCF has a significant positive effect on GDP. Here, the implication is that a unit increase in INV will result to 0.3123 units increase in GDP.

\section{Summary, Conclusion and Recommendations \\ Summary}

This study investigated the link between financial sector polices represented by gross capital formation (GCF), total insurance premium (INP) and total insurance investment (INV), and gross domestic product (GDP) proxy for economic growth in Nigeria. From the results of analysis in the preceding section, the findings of the study are summarized as follows:

1. GCF has a significant negative effect on GDP with a coefficient of -0.23 (approx.) and 0.03 P-value which is less than 0.05 critical value;

2. INP has a negative but insignificant effect on GDP with a coefficient of -0.03 (approx.) and P-value of 0.47 which is greater than 0.05 critical value; and

3. INV had a significant positive effect on GDP with a coefficient of 0.31 and P-value of 0.00 which is below the 0.05 level of significance.

\section{Conclusion}

This study investigated the financial sector policies and economic growth link in Nigeria with a focus more on the insurance sub-sector. The study adopted the ex post facto time series research design, where data for evaluation covering the period 2010 to 2018 were obtained from several editions of the Central Bank of Nigeria (CBN) Statistical Bulletin. Gross capital formation, total insurance premium and total insurance investment were used to represent financial sector policies, while gross domestic product was used as proxy for economic growth. Data were analyzed using descriptive statistics and multiple regression technique assisted by E-views 10 software. The study found that gross capital formation and total insurance investment were significantly related to gross domestic product, while total insurance premium had insignificant effect on GDP. Also, gross capital formation and total insurance premium had negative effect on GDP, but total insurance investment was positively related to GDP. The study concluded that financial sector policies made statistically substantial contribution to the growth of the Nigerian economy with a coefficient of determination 
INTERNATIONAL JOURNAL OF ACADEMIC RESEARCH IN BUSINESS AND SOCIAL SCIENCES Vol. 10, No. 9, 2020, E-ISSN: 2222-6990 @ 2020 HRMARS

and probability of F-statistics values of 0.99246 and 0.00001 (less than 0.05 level of significance) respectively. It is therefore recommended that the regulatory authorities should put in place policies to make it attractive for Nigerians to patronize insurance business as this would translate to increased insurance investment and further result to growth of the Nigerian economy since insurance investment was found to have positive link with gross domestic product.

\section{Recommendations}

Based on the findings of the study the following recommendations were made:

1. The regulatory authorities should put in place policies to make it attractive for Nigerians to patronize insurance business as this would translate to increased insurance investment and further result to growth of the Nigerian economy since insurance investment was found to have positive link with gross domestic product. Also, the operatives in the sub-sector should carry out public sensitization and enlightenment campaigns in order to increase public patronage of insurance products.

2. More attention should be given by government, through proactive regulatory policies and insurance companies to develop good insurance policies and practices that are not misleading but very clear in content for more understanding by insured or the public as this will enable more people to take insurance cover which will thereby increase the financial base of the companies in that sector.

3. Industry operators should ensure reduction in insurance premium as increases would lead to decrease in gross domestic product.

\section{Contribution to Knowledge}

This study contributed to knowledge by examining the relationship between gross capital formation (for the overall financial system), total insurance investment (life and non-life), total insurance premium (life and non-life) and economic growth using a simplified and easy to understand model. It provided further insights from a practical demonstration, the important role the insurance subsector played as part of the country's financial system in boosting economic growth. This was made very clear from the findings of the study which revealed that total insurance investment in Nigeria had strong significant effect on economic growth. The study has also provided for policy makers and the regulatory authority a better understanding to put in place policies and legislation that would encourage investors to participate more in the sector to sustain the growth of the economy. Furthermore, the study would remain a useful reference source for future researchers and scholars.

\section{References}

Adebisi, S. A., Umukoro, S. E. O., \& Ohiani, A. S. (2019). Evaluating local content policy of insurance oil and gas risk portfolio as capacity building strategy for Nigeria insurance companies. Academic Journal of Economic Studies, 5(4), 69-77.

Arestis, P., \& Demetriades, P. (1997). Financial development and economic growth: Assessing the evidence. The Economic Journal, 107(442), 783-799. https://doi.org/10.1111/j.14680297.1997.tb00043.x

Babu, G. S. (2018). Role of financial system in economic development of a country. International Journal of Multidisciplinary Research and Development, 5(8), 100-107. 
INTERNATIONAL JOURNAL OF ACADEMIC RESEARCH IN BUSINESS AND SOCIAL SCIENCES

Vol. 10, No. 9, 2020, E-ISSN: 2222-6990 @ 2020 HRMARS

Billah, M. M. (2013). Effect of Insurance on Maritime Liability Law: A Legal and Economic Analysis. Springer International Publishing.

Boon, T. K. (2005). Do commercial banks, stock market and insurance market promote economic growth? An analysis of the Singapore economy (Working Paper). Nanyang Technological University, Nanyang, Singapore, 1-15. www.ceistorvergata.it>XII_Conference>Boon Accessed 09/08/2020

Etale, L. M. (2019). Insurance sector development and economic growth in Nigeria: An empirical analysis. International Journal of Development and Economic Sustainability, 7(4), 34-48.

Etale, L. M., \& Uzakah, T. (2020). Financial Accounting performance indicators and share price: A case study of Zenith Bank Nigeria PLC. Niger Delta Journal of Management Sciences, 1(1), 62-79.

Eze, O. R., \& Okoye, V. (2013). Analysis of insurance practices and economic growth in Nigeria: Using co-integration test and error correction model. Global Advanced Research Journal of Management and Business Studies, 2(1), 063-070.

Fadun, O. S., \& Shoyemi, O. S. (2018). Insurance investment funds and economic growth in Nigeria: An empirical analysis (2000-2015). International Journal of Development and Management Review, 13(1), 73-88.

Fashagba, M. O. (2018). The impact of insurance on economic growth in Nigeria. Afro Asian Journal of Social Sciences, IX (1), 1-10.

Gollier, C. (2003). To insure or not to insure? An insurance puzzle. The Geneva Papers on Risk and Insurance Theory, 28, 5-24.

Haiss, P., \& Sumegi, K. (2008). The relationship between insurance and economic growth: A theoretical and empirical analysis. Empirica, 35(4), 405-431. https://doi.org/10.1007/s10663006-9075-2

Horng, M., Chang, Y., \& Wu, T. (2012). Does insurance demand or financial development promote economic growth? Evidence from Taiwan. Applied Economics Letters, 19(2), 105-111. https://doi.org/10.1080/13504851.2011.568386

Hou, H., \& Cheng, S. (2017). The dynamic effects of banking, life insurance and stock markets on economic growth. Japan and the World Economy, 41, 87-98. https://dx.doi.org/10.1016/j.japwor.2017.02.001

Iyodo, B. Y., Samuel, S. E., \& Inyada, S. J. (2018). Effect of insurance industry performance on economic growth in Nigeria. International Journal of Business and Finance Management Research, 6(2018), 22-33.

Lee, H., Yong, Z., \& Lim, Q. (2018). Insurance development and economic growth. Financial Statistical Journal, 1, 1-17. https://doi.org/10.24294/fsi.v1i4.1057

Montiel, P. J. (1995). Financial policies and economic growth: Theory, evidence and country specific experiences in Sub-Saharan Africa, AERC Special Paper 18, African Economic Research Consortium, 1-42. www.idl-bnc-idrc.dspacedirect.org Accessed 09/08/2020

Nwosa, P. I., \& Mustapha, Z. B. (2018). The dynamics of insurance development and economic growth in Nigeria. The India Economic Journal, 65(1/4), 37-44. https://doi.org/10.1177/0019466217727813

Nwoye, U. J., Obiorah, J. N., \& Ekesiobi, C. (2015). Effect of Nigeria macroeconomic environment on the performance of the national economy: Implications. International Journal of Academic Research in Business and Social Sciences, 5(7), 42-51. https://dx.doi.org/10.6007/IJARBSS/v5$\mathrm{i} 7 / 1708$ 
INTERNATIONAL JOURNAL OF ACADEMIC RESEARCH IN BUSINESS AND SOCIAL SCIENCES

Vol. 10, No. 9, 2020, E-ISSN: 2222-6990 @ 2020 HRMARS

Olushola, O. A., \& Uzoma, M. E. (2018). Financial sector development and economic growth in Nigeria: An econometric analysis, 1981-2017. International Journal of Economics and Financial Management, 3(3), 35-50.

Ouedraogo, I., Guerineau, S., \& Sawadogo, R. (2018). Life insurance development and economic growth: Evidence from developing countries. Journal of Economic Development, 43(2), 1-28. https://doi.org/10.35866/caujed.2018.43.2.001

Outreville, J. F. (2013). The relationship between insurance and economic development: 85 Empirical papers for a review of the literature. Risk Management and Insurance Review, 16(1), 71-122. https://doi.org/10.1111/j.1540.6296.2012.01219.x

Peleckiene, V., Peleckis, K., Dudzeviciute, G., \& Peleckis, K. K. (2019). The relationship between insurance and economic growth: Evidence from the European Union countries. Economic

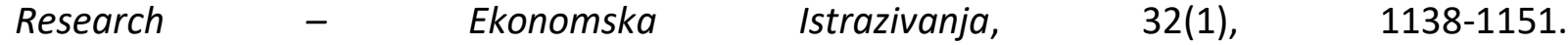
https://doi.org/10.1080/1331677X.2019.1588765

Skipper, H. D. (1997). Foreign insurers in emerging markets: Issues and concerns, IIF Occasional Paper No. 1, International Insurance Foundation, 1-42. www.researchgate.net Accessed 09/08/2020

UI Din, S. M., Abu-Bakar, A., \& Regupathi, A. (2017). Does insurance promote economic growth? A comparative study of developed and emerging/developing economies. Cogent Economics and Finance, 5(1), 1-12. https://doi.org/10.1080/23322039.2017.1390029

UI Din, S. M., Regupathi, A., \& Abu-Bakar, A. (2017). Insurance effect on economic growth - among economies in various phases of development. Review of International Business and Strategy, 27(4), 501-519. https://doi.org/10.1108/RIBS-02-2017-0010

Yinusa, O., \& Akinlo, T. (2013). Insurance development and economic growth in Nigeria, 1986-2010. Journal of Economics and International Finance, 5(5), 218-224.

https://doi.org/10.5897/JEIF2013.0498. 